\title{
Studies on Glucose-6-Phosphatase in Liver and Kidney
}

\author{
II. Relatiohship between Thyroid Hormones and Glucose-6- \\ Phosphatase in Rat Liver and Kidney
}

\section{Hirokazu SUGIYAMA}

2nd Department of Internal Medicine, Gifu University School of Medicine, Gifu, Japan

(Director : Professor S. HAYASE M.D.)

Variation of glucose-6-phosphatase (G6Pase) activity in rat liver and kidney under thyroidal dysfunctioning was investigated on the groups of experimental animals treated as follows:

a) Potassium iodide administration; $10 r$ per day for a week

b) 3,3',5'-Triiodothyronine administration; $5 r$ per day for a week

c) L-Thyroxine administration; 30r per day for a week

d) Mercazole administration; $10 \mathrm{mg}$ per day for a week

e) Thyroidectomy; more than $4 / 5$ of the thyroid gland removed

f) Thyroxine administration (30r per day for a week) after thyroidectomy

\section{Materials and Methods}

Male Wistar rats, with an average weight of $180 \mathrm{~g}$, fed with Oriental solid food (CEII), were used. Each experimental group and control group consisted of 5 animals each. Two per cent liver or kidney homogenate was centrifuged down at $1500 \times \mathrm{g}$ for 5 minutes and $0.1 \mathrm{ml}$ of the supernatant was used as an enzyme source. Sodium salt of glucose-6phosphate as substrate and citrate buffer, $\mathrm{pH}$ 6.5, were employed. The enzyme activity was determined according to Swanson's method and the specific activity was expressed by $\gamma \mathrm{P} / \gamma$ protein (determined by $\mathrm{Cu}-\mathrm{Folin}$ method) $/ 30 \mathrm{~min}$. at $37^{\circ} \mathrm{C}$.

For histochemical examinations, liver and kidney were sliced continuously with Lirde Kryostat as soon as possible after bleeding the animal, and the G6Pase activity was detected by Wachstein-Meisel's method. Histological examination of the Langerhans' islets of the pancreas was performed by Gomori's PHE staining.

\section{Results}

1. Groups with potassium iodide, triiodothyronine and thyroxine administration: A significant increase in the G6Pase activity of both liver and kidney, in comparison with that of the control group, was observed in triiodothyronine- and thyroxine-treated groups, whereas no such influence was revealed in potassium iodide-administered group. The effects of triiodothyronine and of thyroxine on this enzyme activity under the present ex- 
perimental condition were almost in the same order (Table 1.).

2. Mercazole-treated and thyroidectomized groups: Both groups showed a significant fall of the G6Pase activity in both liver and kidney as compared to the activity found in control animals (Table 2.).

3. Group with thyroxine administration after thyroidectomy: Decreased level of the G6Pase activity, as observed following thyroidectomy, was restored almost to the normal value (Table 3.).

Histochemical investigation revealed no particular tissue region responsible for the variation of the G6Pase activity. The principal site of the activity variation in the kidney appears to be in the cells of proximal tubule, while glomerulus has nothing to do with it (Photo. 1,2.).

Histological examinations on the Langerhans' islets of the treated animals revealed no remarkable change in comparison with the control animals, suggesting that the influence of thyroid hormones on the islets is a mild one (Photo. 3.).

From all these results, variation of the liver and kidney G6Pase activity appears to reflect the increased gluconeogenesis in hyperthyroidism and the decreased gluconeogenesis in hypothyroidism. Thus, the kidney enzyme, too, with a behavior similar to that of the liver enzyme, is presumed to contribute to in vivo metabolism. (pp. 769 774) 


\section{肝, 腎 glucose-6-phosphatase に関する研究}

\section{（II）甲状腺ホルモン之肝, 腎 glucose-6-phosphatase そついて*}

岐阜大学医学部第二内科（担当：早瀬正二教授）

杉山弘 和

(昭和43年 2 月 28 日受付)

ホルモン環境変動下におけるラット朋, 腎 G-6-Pase 活性の変動をヨードカリ, $\mathrm{T}_{3}, \mathrm{~T}_{4}$, mercazole 各投与群，甲状腺剔出群，甲状腺出後 $\mathrm{T}_{4}$ 投与群等について，甲状腺ホルモンの面より検討し，合わせ て組織化学的検索，膵ラ氏島の態度の検索も行なつた．肝，腎 G-6-Pase の態度は甲状腺機能六進状態 においては糖新生の立進を, 甲状腺機能低下時には糖新生の低下を反映しているものとみなされた。

\section{緒 言}

著者は前報1)において肝, 腎 glucose-6-phosphatase（以下 G-6-Pase と略）の基本的性状を明らかにし， 腎においても肝同様至適 pH6.5 を有す特異的な phosphatase である G-6-Pase の存在を確認し, 肝と同程 度の活性值を有するととを認めた. 本報においてはホルモン環境変動下におけるラット朋, 筒 G-6-Pase 活 性の変動を甲状腺ホルモンの面より眺め検討した。

\section{実験材料および実験方法}

実験動物はすべてオリエンタル固型飼料（GE-II 型）で飼育した雄性ウィスター系成熟ラット体重 $180 \mathrm{gm}$. 前後のものを使用した.

実験動物は potassium iodide, triiodothyronine, thyroxine, mercazole の各投与群之甲状腺剔出群, 甲 状腺剔出後 thyroxine 投与群を作り, potassium iodide は $10 \gamma /$ 日，3,5',5'-triiodothyronine は $5 \gamma /$ 日, $l$-thyroxine は $30 \gamma /$ 日, mercazole は $10 \mathrm{mg}$ /日を連続 1 週間投与した. 甲状腺剔出群は頸部切開後直視下に 剔出し，剔出した甲状腺を科量し，1 週間後残存甲状腺を科量し $4 / 5$ 以上剔出できたものを実験に使用した. 甲状腺剔出後 thyroxine 投与群は甲状腺剔出後 $l$-thyroxine $30 \gamma /$ 日連続 1 週間投与後の動物を使用した. 対照, 実験動物群はすべて 5 匹用意し各々について肝, 腎 G-6-Pase 活性の変動を検討した.

酵素 : 前報1 に述べた方法にしたがつた。

基質 : 0.1M glucose-6-phosphate $\mathrm{Na}$ 塩 $\mathrm{pH} 6.5$ を使用した.

緩衝液：0.1Mクエン酸緩衝液 $\mathrm{pH} 6.5$ を使用した。

酵素活性測定法ならびに酵素活性值の表現 ( $\gamma \mathrm{P} / \gamma$ protein $\left./ 30 \mathrm{~min} . / 37^{\circ} \mathrm{C}\right), \mathrm{G}-6-\mathrm{Pase}$ の組織化学的検素は 前報 ${ }^{1)}$ に詳述した方法によつた。

萃ランゲルハンス氏島の態度は Gomori のPHE 染色により検討した.

\section{実 験 成 績}

\section{肝, 腎 G-6-Pase 活性値}

1. potassium iodide, triiodothyronine, thyroxine 投与群

* 本論文の要旨は第37回日本内分泌学会総会 (昭. 39. 6. 東京), 第13回日本内分泌学会西日本地方会 （昭. 40. 10. 大阪）にて発表した. 
triiodothyronine, thyroxine 投与群では肝, 腎ともに対照群に比し有意な活性の増加を認めた. Table 1 . に示すように対照群肝活性值 $0.217 \pm 0.024$, 対照群腎活性值 $0.262 \pm 0.015$ 亿対し, triiodothyronine 投与 群肝活性值は $0.330 \pm 0.025$, 同腎活性值は $0.322 \pm 0.032$, thyroxine 投与群では肝活性值は $0.360 \pm 0.027$, 腎活性值は $0.329 \pm 0.052 て ゙$, 腎も肝と同様の態度をとつた。肝, 腎 G-6-Pase 活性に及ぽす triiodothyronine, thyroxine の効果は本実験条件下では同程度であつた，potassium iodide 投与群では肝 $(0.248 \pm 0.023)$ ， 腎 $(0.283 \pm 0.46)$ とも活性值に有意な変動を認めなかつた。

\section{2. mercazole 投与群, 甲状腺剔出群}

Table 2. 亿示すように mercazole 投与群では肝活性值 $0.105 \pm 0.012$, 腎活性值 $0.216 \pm 0.024$, 甲状腺 剔出群では肝活性值 $0.227 \pm 0.015$, 㪝活性值 $0.234 \pm 0.023$ を示し, 対照群肝活性值 $0.262 \pm 0.016$, 腎活性 值 $0.271 \pm 0.014$ 亿比し有意な活性低下を認めた。

Table 1. Effects of potassium iodide, triiodothyronine and thyroxine on liver and kidney G-6-Pase activity in rats

\begin{tabular}{|c|c|c|c|c|c|c|c|c|}
\hline & \multicolumn{4}{|c|}{ Liver } & \multicolumn{4}{|c|}{ Kidney } \\
\hline Animal No. & Gontrol & $\mathrm{KI}$ & $\mathrm{T}_{3}$ & $\mathrm{~T}_{4}$ & Control & $\mathrm{KI}$ & $\mathrm{T}_{3}$ & $\mathrm{~T}_{4}$ \\
\hline 1 & 0.205 & 0.236 & 0.365 & 0.343 & 0.264 & 0.269 & 0.310 & 0.336 \\
\hline 2 & 0.194 & 0.254 & 0.315 & 0.348 & 0.242 & 0.300 & 0.299 & 0.399 \\
\hline 3 & 0.248 & 0.281 & 0.305 & 0.344 & 0.256 & 0.349 & 0.300 & 0.264 \\
\hline 4 & 0.204 & 0.225 & 0.325 & 0.404 & 0.281 & 0.244 & 0.328 & 0.338 \\
\hline 5 & 0.234 & 0.245 & 0.338 & 0.360 & 0.267 & 0.251 & 0.372 & 0.308 \\
\hline$\overline{\mathbf{x}} \pm \mathrm{SD}$ & $\begin{array}{l}0.217 \\
\pm \\
0.024\end{array}$ & $\begin{array}{l}0.248 \\
\pm \\
0.023\end{array}$ & $\begin{array}{c}0.330 \\
\pm \\
0.025^{* *}\end{array}$ & $\begin{array}{c}0.360 \\
\pm \\
0.027 * *\end{array}$ & $\begin{array}{c}0.262 \\
\pm \\
0.015 \\
\end{array}$ & $\begin{array}{c}0.283 \\
\pm \\
0.046 \\
\end{array}$ & $\begin{array}{c}0.322 \\
\pm \\
0.032 *\end{array}$ & $\begin{array}{c}0.329 \\
\pm \\
0.052^{* *} \\
\end{array}$ \\
\hline
\end{tabular}

Activity : $\gamma$ phosphorus liberated per $\gamma$ protein per 30 minutes at $37^{\circ} \mathrm{C}$.

Control : control normal rats, $\mathrm{KI}$ : potassium iodide treated rats, $\mathrm{T}_{3}:$ triiodothyronine treated rats, $\mathrm{T}_{4}:$ thyroxine treated rats.

$* *: \mathrm{p}<0.01, *: \mathrm{p}<0.05$

Table 2. Effects of mercazole and thyroidectomy on liver and kidney G-6-Pase activity in rats

\begin{tabular}{|c|c|c|c|c|c|c|}
\hline & \multicolumn{3}{|c|}{ Liver } & \multicolumn{3}{|c|}{ Kidney } \\
\hline Animal No. & Control & Mercazole & THY X & Control & Mercazole & THY X \\
\hline 1 & 0.244 & 0.090 & 0.231 & 0.278 & 0.180 & 0.199 \\
\hline 2 & 0.276 & 0.104 & 0.211 & 0.286 & 0.216 & 0.258 \\
\hline 3 & 0.261 & 0.122 & 0.242 & 0.256 & 0.235 & 0.231 \\
\hline 4 & 0.250 & 0.104 & 0.238 & 0.276 & 0.218 & 0.240 \\
\hline 5 & 0.279 & 0.105 & 0.214 & 0.258 & 0.232 & 0.240 \\
\hline$\overline{\mathbf{x}} \pm \mathrm{SD} \#$ & $\begin{array}{l}0.262 \\
\pm \\
0.016\end{array}$ & $\begin{array}{c}0.105 \\
\pm \\
0.012^{* *}\end{array}$ & $\begin{array}{c}0.227 \\
\pm \\
0.015^{* *}\end{array}$ & $\begin{array}{c}0.271 \\
\pm \\
0.014 \\
\end{array}$ & $\begin{array}{c}0.216 \\
\pm \\
0.024^{* *} \\
\end{array}$ & $\begin{array}{c}0.234 \\
\pm \\
0.023^{*} \\
\end{array}$ \\
\hline
\end{tabular}

Activity is expressed as shown in Table 1.

Control : control normal rats, Mercazole : mercazole treated rats,

THY X : thyroidectomized rats.

\#: mean with standard deviation.

$* *: \mathrm{p}<0.01, *: \mathrm{p}<0.05$ 
Table 3. Effect of thyroxine after thyroidectomy on liver and kidney G.6Pase activity in rats

\begin{tabular}{|c|c|c|}
\hline Animal No. & Liver & Kidney \\
\hline 1 & 0.362 & 0.328 \\
\hline 2 & 0.310 & 0.349 \\
\hline 3 & 0.322 & 0.317 \\
\hline 4 & 0.336 & 0.334 \\
\hline 5 & 0.353 & 0.306 \\
\hline$\overline{\mathrm{x}} \pm \mathrm{SD} \Psi$ & $0.337 \pm 0.023^{* *}$ & $0.327 \pm 0.007^{* *}$ \\
\hline
\end{tabular}

Activity is expressed as shown in Table 1. \#: mean with standard deviation.

** $: \mathrm{p}<0.01$, compared with thyroidectomized rats (Table 2).

Photo. 1. Distribution of G-6-Pase in thyroidectomized rat kidney. $(\times 100)$

The enzymatic activity decreased, compared with that of normal rat kidney. Incubated for 15 minutes in G6-P, adjusted to $\mathrm{pH} 6.5$.

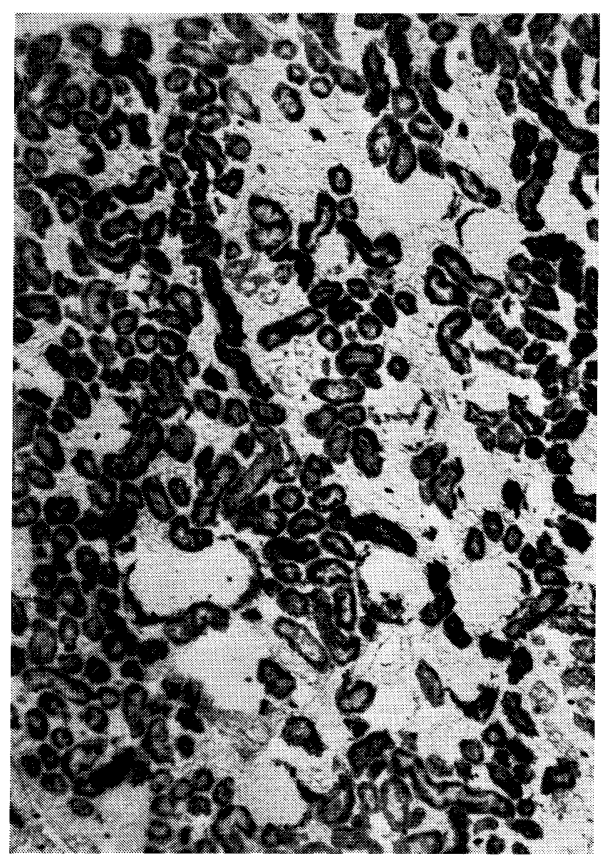

Table 4. Summary of histochemical study on liver and kidney G-6-Pase activity in rats

\begin{tabular}{|c|c|c|}
\hline & Liver & Kidney \\
\hline Potassium iodide & unchanged & unchanged \\
\hline Triiodothyronine & increased & increased \\
\hline Thyroxine & increased & increased \\
\hline Mercazole & decreased & decreased \\
\hline Thyroidectomy & decreased & decreased \\
\hline $\begin{array}{l}\text { Thyroidectomy } \\
+ \text { Thyroxine }\end{array}$ & increased & increased \\
\hline
\end{tabular}

Compared with normal rats.

Photo. 2. Distribution of G-6-Pase in thyroxine treated rat kidney after thyroidectomy. $(\times 100)$

The enzymatic activity increased, compared with that of normal and thyroidectomized rat kidney.

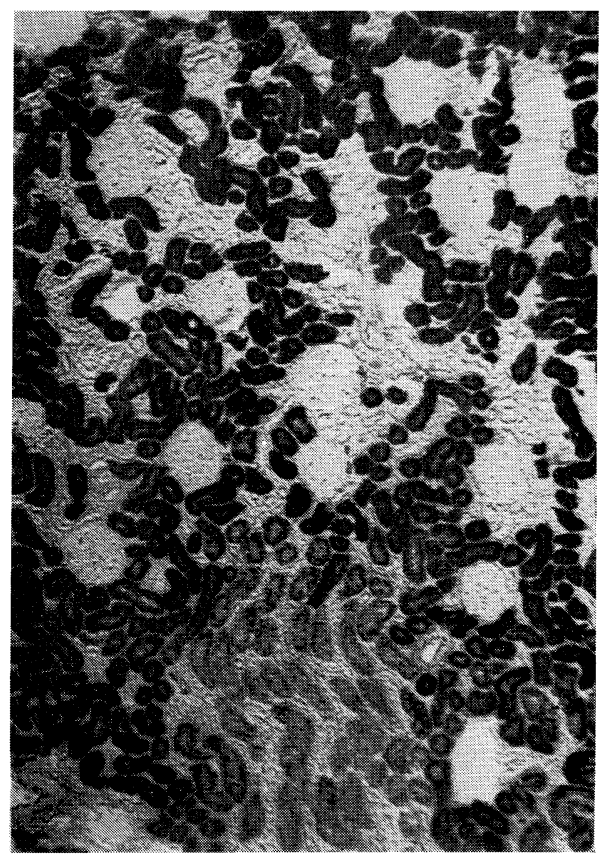


Photo. 3. Islet of Langerhans' in thyroxine treated rat. No appreciable change in islet was observed, compared with those in normal rat. (PHE, $\times 100$ )

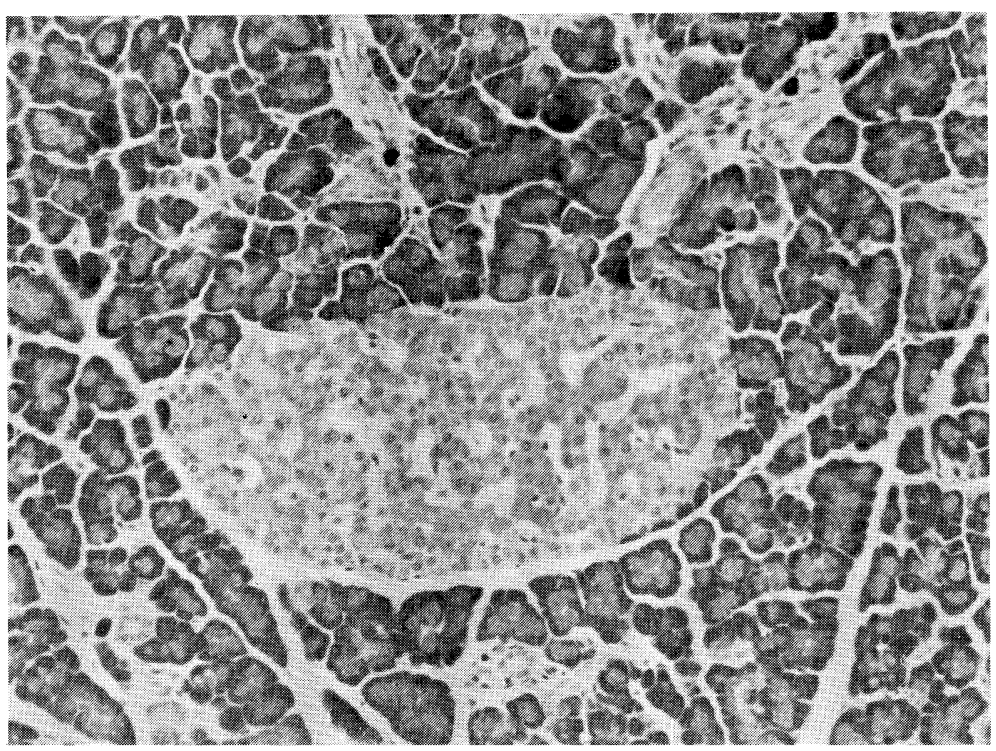

\section{3. 甲状腺剔出後 thyroxine 投与群}

肝，腎の活性值は Table 3. に示されるごとく各々の活性值は $0.337 \pm 0.023$, 及び $0.327 \pm 0.007$ である. これらの活性值は Table 2. の甲状腺剔出群, 刘照群に比して有意な活性の復活を示した。

\section{肝, 腎 G-6-Pase の組織化学的検索}

Table 4. に示すように組織化学的検査においても活性測定值の変動と同一の態度をとつた. Photo. 1. 亿 甲状腺剔出動物の，Photo. 2. 亿阵状腺剔出後 thyroxine 投与動物の腎 G-6-Pase を示したが，正常対照群 に比しこれらの群では前者では明らかに活性の低下を，後者では活性の復活を認めている，各処置群におけ 腎における組織上の活性変動の部位的特徴は認められなかつた。腎における活性変動の主要部位は近位尿細 る組織化学的変動の肝，管細胞で糸球体はまつたく関与していなかつた。

\section{甲状腺機能変動時の膵ランゲルハンス氏島の態度}

上述の実験に供した thyroxine 投与群, 甲状腺剔出群, 甲状腺剔出後 thyroxine 投与群の膵ランゲルハ ンス氏島を Gomori のPHE 染色によつて対照群と比較検討したが，膵ランゲルハンス氏島の態度はいずれ の群においても対照群に比し著変を認めず, 正常ラット膵ランゲルハンス氏島所見と変るととがなかつた。 Photo. 3. 乙れらの群の代表例として thyroxine 投与動物の蓃ランゲルハンス氏島所見を示した．正常対 照群の猝ランゲルハンス氏島所見と何んら変るとてろがない.

\section{考案}

甲状腺ホルモンは酸化に大きな作用を示す他, 脂質, 蛋白質代謝にも多彩な影響を及ぼすが, 糖代謝にお ける効果としては Wertheimer $ら^{233}$ は少量の thyroxine は肝糖原を增加させ, 過量の thyroxine はそれを 減少さすとし，糖原の代謝との密接な関係を指摘した。 またNecheles $ら^{4)}$ の赤血球の実験では甲状腺ホル モンが直接解糖系仁作用する可能性をのべている。

甲状腺機能立進時の変化としては Spiro ら ${ }^{5)}$ はラットで嫌気性ならびに好気性解糖がともに促進するてと を認めた。乞の他, 糖利用の促進 ${ }^{6)}$, 腸管からの糖吸収の促進 ${ }^{7)}$, 肝 glycogenesis $の$ 減少 ${ }^{8)}$, glycogenolysis 
の増加9)などが認められ，肝 G.6-Pase に関しては thyroxine 投与による活性の増加が報告されている(0)11). 甲状腺機能低下時の変化としては腸管からの糖吸収の遅延が知られているが, 藤田 ${ }^{12)}$, 䛀本 ${ }^{13)}$ らは肝 G-6-Pase 活性の減少と肝糖原の増加を認めている.

本研究の結果についてまとめてみると G-6-Pase は甲状腺ホルモン投与で活性上昇し, 抗甲状腺剤の投与 や甲状腺剔出で活性低下が認められた。 甲状腺機能の異常に G-6-Pase が敏感に反応して変動しているてと が認められる. 甲状腺ホルモン過剩においては糖原の減少と酸化の元進が著明であり, 正常の血糖を維持す るにはより多く糖新生系に依存しなければならないであろう。また甲状腺機能低下時には肝糖原は减少せず 代謝が全体として低下するので血糖の維持に対する糖新生系の依存度も減少するものと思われる。乙のよう 飞考元ると本研究の G-6-Pase 活性の動きはよく糖新生系の態度を反映しているものと思われる ${ }^{14)}$. 著者の

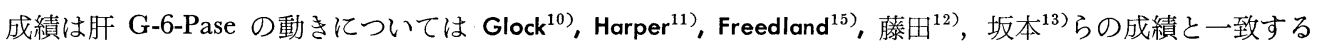
結果であるが, 豧 G-6-Pase が肝のそれと全く同じ態度で変動しているととが注目される，従来糖代謝の中 枢藏器として肝のみ重視され腎のとの方面の機能はほとんぞ顧みられなかつた。本実験成績は腎においても 肝と同じく甲状腺機能失調時に生体内糖代謝に寄与しているのであろうことを G-6-Pase の消長から強く示 唆する.

なお上記の G-6-Pase の変動に関する甲状腺ホルモン作用機序については不明であり,その解明は in vitro でのホルモン効果を知る必要があるが, 本醭素の失活防止の問題が解決されない限り in vitro の研究は困難 である.

また甲状腺機能六進における insulin response の充進の報告 ${ }^{16)}$ もるので膵ランゲルハンス氏島の組織 学的な検索を陚みたのであるが，正常と著変のない結果であつた．形態と機能は必ずしも一致しないが cortisol 投与の場合などの著明な変化 ${ }^{17)}$ から考劣ると甲状腺ホルモンの膵ランゲルハンス氏島に対する影響 は緩和なものと推測される。

結 語

ラットにおける肝, 腎 G-6-Pase 活性を甲状腺機能失調の条件下に検索し次の結果を得た.

1. triiodothyronine, thyroxine 投与群では肝, 腎ともに対照群に比し有意な活性の增加を認めた。 potassium iodide 投与群では肺, 腎とも有意な変動を認めなかつた。

2. mercazole 投与群, 甲状腺剔出群では肝, 腎ともに対照群に比し有意な活性低下を認めた。

3. 甲状腺剔出後 thyroxine 投与群は甲状腺剔出群, 正常対照群に比して有意な活性の復活を示した。

4. 組織化学検討にわいても活性測定值の変動と同一の態度をとつた。各処置群における組織化学的変動 の肝, 腎における組織上の活性変動の部位的特徴は認められなかつた。系球体は活性変動に関与せず腎での 活性変動の主要部位は近位尿細管細胞であつた。

5.甲状腺機能変動時の膵ランゲルハンス氏島の態度はいずれの実験群においても対照群に比し著変を認 めず正常ラット脺ランゲルハンス氏島所見と変るととがなかつた。

肝, 槃 G-6-Pase の態度は甲状腺機能立進状態においては糖新生の元進を, 甲状腺機能低下時には糖新生 の低下を反映しているものとみなされ，靕においても肝と同様の態度を G-6-Pase はとり生体内反応に寄与 しているものと思われる。

終りに臨み，御校閲を賜わつた早瀬正二教授，御助言を睗わつた木島滋二前教授，法医学教室須山弘文教 授に深謝するとともに, 終始御指導御鞭撞を睗わつた竹内三郎講師に深謝する。また法医学教室前岡勇夫博 士, 中央検查室青木敦学兄の御教示, 御助言飞感謝する.

文献

1) 杉山弘和：日内分泌誌，44:760,(1968).

2) WERTHEIMER, E. and V. BENTOR : Metabolism, 第44巻 第 7 号 
$2: 536$, (1953). 3) WERTHEIMER, E., V. BENTOR and M. WURZEL : Biochem. J., $56: 297$, (1954). 4) NECHELES, T., and E. BEUTLER : J. Clin. Invest., $38: 788,(1959) . \quad 5)$ SPIRO, M.J. and E.G. BALL : J. Biol. Chem., $231: 31$, (1958). 6) AMATUZIO, D.S., A.L. SGHULTZ, M.J. VANDERBILT, E.D. RAMES and S. NESBETT : J. Clin. Invest., 33 : 97, (1954). ALthauSEN, T.L. and M. STOCKHOLM : Amer. J. Physiol., $123: 577,(1938) . \quad$ 8) JOHN, H.J. : Ann. Int. Med., $4: 501$, (1930). $\quad$ 9) LONG, C. Jr., G. KILO and L. REGANT : Diabetes, $13: 127$, (1964). $\quad$ 10) GLOGK, G.E., P. MGLEAN and J.K. WHITEHEAD : Biochem. J., $63: 520$, (1956). 11) HARPER, A.E. : Biochem. J., $64: 14,(1956) . \quad 12)$ 藤田輝雄 : 日内分泌誌, $38: 565,(1962)$ 13) SAKAMOTO, K. : Jap. Arch. Int. Med., $12: 387$, (1965). 14）竹内三郎, 細川祜正, 杉下 功, 杉山弘和: 診療, 18:43, (1965). 15) FREEDLAND, R.A. : Endocrinology, 77 : 19. (1965). 16) ELRIGK, H., C.J. Jr. HLAD and Y. ARAI : J. Clin. Endocr., $21: 387,(1961)$ 17) 翠川 修: 最新医学, 19:543, (1964). 